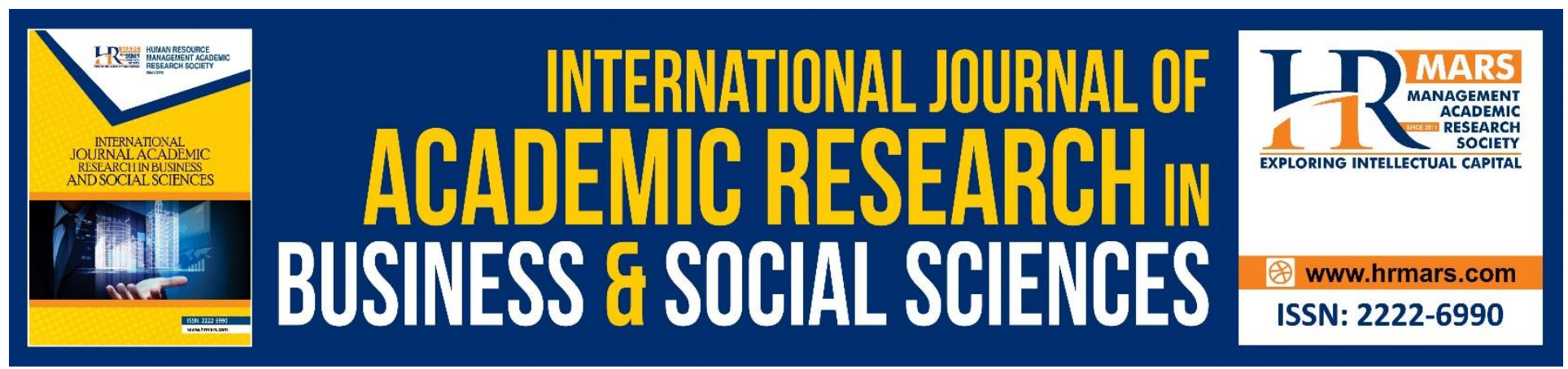

\title{
An Analysis of Puffery in Advertising Slogans
}

Farahani Halim, Zulkarnian Ahmad, Nor Jijidiana Azmi, Nor Azikin Mohd
Omar

To Link this Article: http://dx.doi.org/10.6007/IJARBSS/v10-i7/7478

DOI:10.6007/IJARBSS/v10-i7/7478

Received: 07 April 2020, Revised: 03 May 2020, Accepted: 20 June 2020

Published Online: 28 July 2020

In-Text Citation: (Halim, Ahmad, Azmi, \& Omar, 2020).

To Cite this Article: Halim, F., Ahmad, Z., Azmi, N. J., \& Omar, N. A. M. (2020). An Analysis of Puffery in

Advertising Slogans. International Journal of Academic Research in Business and Social Sciences. 10(7), 626-

631.

Copyright: (c) 2020 The Author(s)

Published by Human Resource Management Academic Research Society (www.hrmars.com)

This article is published under the Creative Commons Attribution (CC BY 4.0) license. Anyone may reproduce, distribute, translate and create derivative works of this article (for both commercial and non-commercial purposes), subject to full attribution to the original publication and authors. The full terms of this license may be seen

at: http://creativecommons.org/licences/by/4.0/legalcode

\section{Vol. 10, No. 7, 2020, Pg. 626 - 631}

Full Terms \& Conditions of access and use can be found at http://hrmars.com/index.php/pages/detail/publication-ethics 


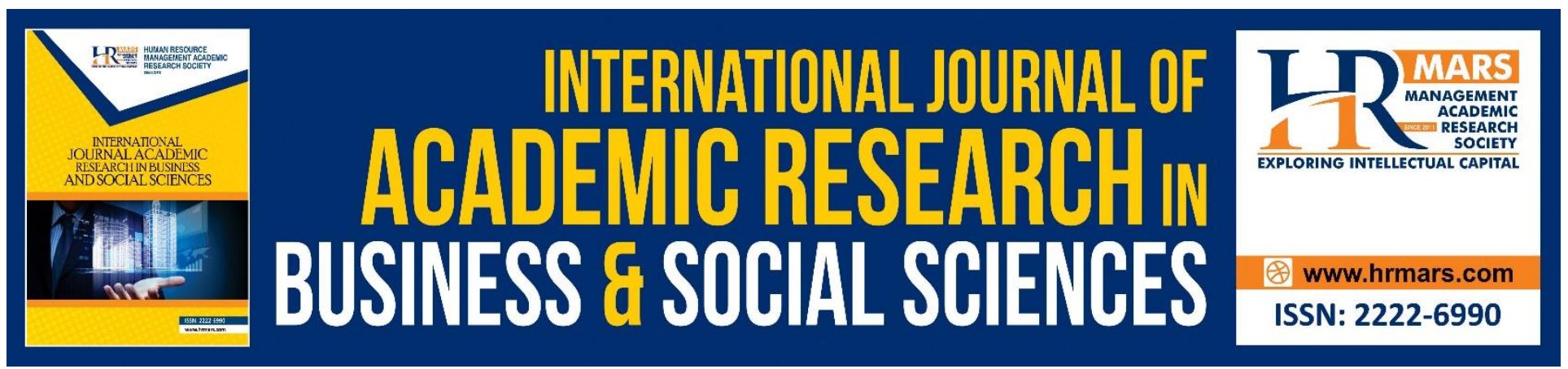

\title{
An Analysis of Puffery in Advertising Slogans
}

\section{Farahani Halim¹, Zulkarnian Ahmad², Nor Jijidiana Azmi' ${ }^{1}$, Nor Azikin Mohd Omar}

${ }^{1}$ Faculty of Languages and Communication, Universiti Sultan Zainal Abidin, 21300 Kuala Terengganu,

Terengganu, Malaysia, ${ }^{2}$ UniKL Business School, Universiti Kuala Lumpur, 50300 Kuala Lumpur, Malaysia

Email: jijidianaazmi@unisza.edu.my

\begin{abstract}
Puffery usually been used in beauty product advertisements especially in a cosmetic product as it is a major expenditure for many women. We conducted a content analysis on two beauty magazines in Malaysia that are Female and Cleo. We aim to identify the elements of puffery in the advertising slogans that are used by beauty products company in advertising their products in the magazines. Result shows that Female magazines has $74.5 \%$ puffery slogans while Cleo employs $25.5 \%$ puffery in the advertising slogans. On top of that, results also shows that the beauty products that employ puffery in the advertising slogans decrease from 2015 to 2018. Based from the results, we conclude that the usage of puffery in advertisements decrease over the years as it is viewed as less effective and exaggerated.
\end{abstract}

Keywords: Slogans, Puffery, Advertisement, Beauty, Product.

\section{Introduction}

The intense rivalry in today's marketing has forced companies to go great length in constructing effective advertising strategies to sell a product and win the consumers' heart. We live in an extremely advertisement-driven world where the society is motivated by consumers and economic success. According to Zhang et al. (2006) we are exposed to nearly 500 advertisements every day, 182,000 every year, and almost millions in a lifetime. These various advertisements are now ubiquitous and that makes us nonchalant to think about its function as a form of discourse and a system of language use.

Strutton, Hamilton \& Lumpkin (1997) stated that marketers are constantly searching for better alternatives to increase sales volume while considering the ethical issue. This is because ethical marketing practices bring more sales and long-term sales relationships with customers. One of the most successful techniques used by powerful advertisers these days is by using puffery in their product advertisement. Preston (1975) defined puffery as advertising or other representations in which praise the product to be sold by subjective opinion, superlatives, or exaggerations, vaguely and generally, stating no specific facts. 
However, puffery should not be confused with false advertising. The difference between puffery and false advertising is by looking at how fact are presented in the advertisement while false advertising consists of objective statements which can be verified. An advertisement can only be considered deceptive if it communicates using facts through statement, implication or omission which differ from reality of situation and it has potential to effect consumer's buying behaviour (Rotfeld and Rotzoll, 1980). According to Leech (1972), there are four different types of advertising including commercial consumer advertising, prestige advertising, industrial or trade advertising and also non-commercial advertising that are exposed to us in our everyday life. Therefore, this paper will specifically analyse on the use of puffery in beauty advertising slogan in influencing and persuading the customers into buying the beauty products.

\section{Beauty Products Advertisement}

Women in today's world have been flooding with a manipulative ideology of beauty through beauty advertisement in which they constructed a problem within individual that can only be solved by using their products. These advertisements can also be found mostly in women magazine, newspaper or even billboard claiming remarkable results in few days.

There are also a lot of beauty whitening product over-claiming their product to be effective instantly upon application and these possibly lead to manipulate readers to believe in whatever advertised is true. These instant whitening products are also increasing abruptly due to the mind set of most Malaysian that beauty is defined as having fair skin.

\section{Puffery in Beauty Product Advertisement}

Magazines are one of the powerful media that regularly reach a vast number of supports from women. These advertisements tend to manipulate readers especially women as their target audience to believe on whatever advertise is true and one of the strategies to convince women is by using puffery in their product claiming.

Although puffery considered as legal promotion, it is still an ethical issue as the exaggerated product claims prompt consumers to buy product that unbeneficial towards them. The companies are also forced to match the puffery claim with the real product and this tends to result in loss of advertising efficiency. After all consumers will lose faith in the system as they get used of companies over-claiming their products exceed their own product capabilities.

The puff claim can be found mostly in the product advertising slogans or even in the product description as it intended to attract their targeted customers to believe in them and engage with their product or service when they see the advertisement. Thus, this paper aims to identify how many beauty company employ puffery and how they use puffery as a language strategy in their product advertising slogans to catch women's attention towards their product.

Ringrow (2016), stated that cosmetic or beauty advertising should be analysed to enables the consumers to be more critically engaged with the ever-pervasive of beauty advertising and provide us the tools to unpack product claims in advertising. These will enables us consider how consumers may challenge the ways in which they are addressed through beauty advertising discourse.

D'Alvise (2012), stated that the uses of puffery in marketplace not only convolutes the deception in advertising, but also it allows advertisers claiming their product to generate attention in which will lead to sales. In this case, employing puffery in promoting the beauty product prompt to 
INTERNATIONAL JOURNAL OF ACADEMIC RESEARCH IN BUSINESS AND SOCIAL SCIENCES

Vol. 10, No. 7, July, 2020, E-ISSN: 2222-6990 @ 2020 HRMARS

mislead woman and make them buy unnecessary product or product quality that doesn't meet with the puff claim.

\section{Methodology}

This study used purposive sampling in order to explore the use of puffery in beauty product advertising slogan. The data for this study was collected from two (2) beauty magazines which are Female and Cleo from January 2015 to December 2018 issues. A content analysis is conducted on the magazines to identify the frequency of puffery advertising slogans that appear in the respective magazines. Magazine has been chosen as the data sampling rather than other printed advertisement such as newspaper because this study focuses on the beauty advertisement. The researchers believe that magazine contains more beauty related advertisement especially in a beauty magazine in which woman is set as their targeted audience. There are various types of magazine in the market but this study only focuses on beauty magazine to explore the pattern of strategy used by company especially in attracting women's attention.

\section{Result}

This section presents the finding and discussion of the data collected from the beauty magazines. The finding and discussion are divided into three main parts in analysing the puffery advertising slogan. Advertising slogan usually short yet eye-catching towards the audience in order to emphasize the identity of the brand. Company in today's marketing are competing with each other in order to come out with different image among others. Therefore, some companies choose to employ puffery as part of their advertising strategy. Puffery advertisement can be identified through text and visual of the advertisement and this paper study on the use of textual puffery only through the slogan of the product beauty advertisements.

Table 1: Frequency of puffery slogans in Malaysian beauty magazines

\begin{tabular}{|c|c|c|c|c|c|}
\hline \multirow{2}{*}{ Magazine } & \multicolumn{4}{|c|}{ Number of puffery slogan } & \multirow{2}{*}{ Total } \\
\cline { 2 - 5 } & $\mathbf{2 0 1 5}$ & $\mathbf{2 0 1 6}$ & $\mathbf{2 0 1 7}$ & $\mathbf{2 0 1 8}$ & \\
\hline \multirow{2}{*}{ Female } & $\begin{array}{c}14 \\
(29.8 \%)\end{array}$ & $\begin{array}{c}10 \\
(21.3 \%)\end{array}$ & $\begin{array}{c}7 \\
(14.9 \%)\end{array}$ & $\begin{array}{c}4 \\
(8.5 \%)\end{array}$ & $\mathrm{n}=35(74.5 \%)$ \\
\hline Cleo & $\begin{array}{c}4 \\
(8.5 \%)\end{array}$ & $\begin{array}{c}3 \\
(6.4 \%)\end{array}$ & $\begin{array}{c}3 \\
(6.4 \%)\end{array}$ & $\begin{array}{c}2 \\
(4.3 \%)\end{array}$ & $\mathrm{n}=12(25.5 \%)$ \\
\hline
\end{tabular}

Based on the analysis, Table 1 shows the result of the frequency of advertisement slogan that employs puffery in the beauty product advertising slogans found in the two (2) beauty magazines that are Female and Cleo. Result shows that Female magazine have 35 number that equals to $74.5 \%$ that employ puffery in the advertising slogans. Meanwhile, Cleo has less puffery slogans in comparison to Female. Cleo has only 12 number of slogans which employ puffery, and this is equal to $25.5 \%$.

Based on data analysis, the result shows that the amount of advertisement that employs puffery in their product advertising slogan is decreasing from 2015 to 2018 . Puffery is a claim which promotional in nature where it's usually subjective and not to be taken seriously. There's a reason why puffery as a form of marketing has existed for a long time and still be persist until today. Puffery 
usually claim that the product will solve a problem in your life, shows how much money you can save and overemphasized trivial traits which eventually make you change your vote.

The arrival of puffery statement can be found since the sixteenth century where the marketplace and the legal approach to selling products or services were very different from today (Preston, 1996). However, the rationale behind the puffery claim has changed. Osovsky (2013) stated that the reasoning has shifted through the years from assuming that the buyer checks his or her purchased object before buying to presuming that nobody relies on puffery statements. This assumption has been clearly articulated in early 1887 where the law has recognized the fact that people will naturally over claim the value or qualities of the product or service that they are selling and people know that buyer has no right to depend on such statements.

The legal issues and risks of using puffery can be one of the reasons why the number of puffery advertisement is slowly decreasing in today's market place. Most of the developed countries are closely monitored the messages in advertisement where all the claims must be strongly supported by scientifically proven evidence. For instance, in United States, the product liability is strictly enforced and there are few companies that have been brought to the court for the misleading claims.

\section{Conclusion}

Employing puffery is a good strategy and beneficial in promoting a product or service. However, the effectiveness is limited as it depends on the consumer's attitude. This claim can be supported by Xu \& Wyer (2010). Based on their study, the finding shows consumer who perceived that they have higher knowledge about the particular product evaluated the product more favourably especially when the ads come from a professional magazine. On the other hand, when the relative knowledge of the consumer towards the product advertisement is low, the consumers' evaluation on the product advertisement from a popular magazine is less favourable. Thus, Consumer who is more familiar with a product has less tendency to be affected by puffery claim because they are more knowledgeable about the product and make them able to spot the points which for them, make no sense and eventually decreasing the effectiveness of the puffery in the advertisement.

This decreasing number of puffery advertisement can be related with the growing amount of information available to the customers. The growth of numerous technologies in this era provided us with easily-access information. Consumers can easily browse the information of the product at the tip of their hands with one click away. Recent study by Merritt, et.al (2018) has found that consumers nowadays do not want to receive push marketing messages but they prefer to search for information that they seek by themselves and more receptive to marketing messages from people instead of from the brands directly. This had made the usage of puffery in advertisement less effective because consumers are not easily influenced by the exaggerated claim on the product but focus on the important information that they need.

\section{References}

D'Alvise, J. (2012). An Investigation into the Persuasiveness of Puffery in Advertising: A Mixed Method Approach. Marketing and Consumer Studies, 1-25.

Leech, G. (1972). English in advertising. A Linguistic Study of advertising in Great Britain. United Kingdom: Longman.

Merritt, M. G., Delong, K.L ., Griffith, A. P., \& Jensen, K. L. (2018). Consumer willingness to pay for Tennessee certified beef. Journal of Agricultural and Applied Economics, 50(2), 233-254. 
INTERNATIONAL JOURNAL OF ACADEMIC RESEARCH IN BUSINESS AND SOCIAL SCIENCES

Vol. 10, No. 7, July, 2020, E-ISSN: 2222-6990 @ 2020 HRMARS

Osovsky, A. (2013). The misconception of the consumer as homo economicus: A behaviouraleconomic approach to consumer protection in the credit reporting system. Suffolk University Law Review, 46(3), 881-993.

Preston, I. (1996). Books on Google Play The great American blow-up: puffery in advertising and selling. University of Wisconsin Press.

Ringrow, H. (2016). The Language of Cosmetics Advertising (1st ed., pp. 1-11). United Kingdom: Palgrave Macmillan.

Strutton, D. J., Hamilton, III, B. \& Lumpkin, J. R. (1997). An essay on when to fully disclose in sales relationships: Applying two practical guidelines for addressing truth-telling problems. Journal of Business Ethics, 16, 545-460.

Rotfeld, H., and Rotzoll, K. (1980). Is Advertising Puffery Believed?. Journal of Advertising, 9(3), pp.1645.

Xu, A. J., \& Wyre, R. S. (2010). Puffery in advertisement: The effects of media context, communication norms, and consumer knowledge. Journal of Consumer Research, 37(2), 329-343.

Zhang, Y. B., Harwood, J., Williams, A., Ylanne-McEwen, V., Wadleigh, P. M., \& Thimm, C. (2006). The portrayal of older adults in advertising: A cross-national review. Journal of Language and Social-Psychology, 25(3), 264-282. 